\section{Container-grown Ornamental Plant Growth and Water Runoff Nutrient Content and Volume Under Four Irrigation Treatments}

\author{
Aaron L. Warsaw ${ }^{1}$ and R. Thomas Fernandez ${ }^{2,3}$ \\ Department of Horticulture, Plant and Soil Sciences Building, Michigan \\ State University, East Lansing, MI 48824
}

\author{
Bert M. Cregg ${ }^{2}$ \\ Departments of Horticulture and Forestry, Plant and Soil Sciences Building, \\ Michigan State University, East Lansing, MI 48824
}

\section{Jeffrey A. Andresen ${ }^{2}$ \\ Department of Geography, 236 Geography Building, Michigan State University, East Lansing, MI 48824}

Additional index words. daily water use, irrigation scheduling, nursery production, overhead irrigation, volumetric moisture content, water conservation

\begin{abstract}
Container-grown woody ornamentals were irrigated according to a percentage of daily water use (DWU) or a traditional irrigation rate to evaluate plant growth, irrigation volume, runoff, and nutrient loss from each irrigation treatment. Deutzia gracilis Sieb. and Zucc. 'Duncan', Kerria japonica (L.) DC. 'Albiflora', Thuja plicata D. Don. 'Atrovirens', and Viburnum dentatum L. 'Ralph Senior' were grown in 10.2-L (\# 3) containers under four overhead irrigation treatments: 1) a control irrigation rate of $19 \mathrm{~mm}$ per application (control); 2) irrigation scheduled to replace $100 \%$ DWU per application (100DWU); 3) irrigation alternating every other application with $100 \%$ replacement of DWU and 75\% DWU (100-75); and 4) irrigation scheduled on a threeapplication cycle with one application of $100 \%$ DWU followed by two applications replacing 75\% DWU (100-75-75). Applications were separated by at least $24 \mathrm{~h}$. Total irrigation applied for the 100DWU, 100-75, and 100-75-75 treatments was $33 \%, 41 \%$, and $44 \%$ less, respectively, than the total water applied by the control treatment of $123 \mathrm{~L}$ per container. Plants grown under the three DWU treatments had a final growth index greater than or equal to plants irrigated by the control treatment depending on species. Daily average runoff volumes from production areas irrigated with $100 \%$ and $75 \%$ DWU were $66 \%$ and $79 \%$ lower than average control runoff of $11.4 \mathrm{~L} \cdot \mathrm{m}^{-2} \cdot \mathrm{d}^{-1}$ across all collection days. Quantity of $\mathrm{NO}_{3}{ }^{-}-\mathrm{N}$ lost daily across all collection days for the $100 \%$ DWU and $75 \%$ DWU irrigation volumes averaged $38 \%$ and $59 \%$ less, respectively, than the control. Daily losses of $\mathrm{PO}_{4}{ }^{3-}-\mathrm{P}$ quantities across all collection days under the $100 \%$ and $75 \%$ DWU volumes were $46 \%$ and $74 \%$ lower, respectively, compared with the control. Irrigating according to the DWU treatments used in this study reduced irrigation and runoff volumes and $\mathrm{NO}_{3}{ }^{-}-\mathrm{N}$ and $\mathrm{PO}_{4}{ }^{3-}-\mathrm{P}$ losses compared with a control of $19 \mathrm{~mm}$ per application while producing the same size or larger plants.
\end{abstract}

Received for publication 15 Apr. 2009. Accepted for publication 18 June 2009.

This research was funded by Michigan State University Project GREEEN and the Michigan Department of Agriculture Horticultural Fund. Additional support provided by Spring Meadow Nursery, Inc. for supplying the plant material; Renewed Earth, Inc. for supplying potting substrate; and Harrell's, Inc. for supplying fertilizer.

The use of company or product names in this publication does not imply endorsement.

This paper is from a thesis submitted by the senior author in partial fulfillment of the requirements for the M.S. degree.

${ }^{1}$ Graduate Assistant

${ }^{2}$ Associate Professor.

${ }^{3}$ To whom reprint requests should be addressed; e-mailfernan15@msu.edu. away from production areas into surrounding water resources.

Contamination of the environment by nursery runoff is classified as nonpoint source pollution (Fain et al., 2000). Yeager and Cashion (1993) reported $\mathrm{NO}_{3}{ }^{-} \mathrm{N}$ concentrations from controlled-release fertilizers (CRF) in runoff periodically exceeded the $10 \mathrm{mg} \cdot \mathrm{L}^{-1}$ federal drinking water standard as established by the U.S. Environmental Protection Agency in 1982. Concerns about contamination of water resources by nursery runoff have risen as awareness of impacts on environmental and human health has increased. Nutrient management laws that limit nutrient concentrations in runoff have been established in Maryland, Delaware, and California (Beeson et al., 2004). To meet current legislation, prepare for future legislation, and ease mounting public concern, ways to reduce runoff without detracting from plant growth must be developed.

One way to reduce runoff is by irrigating according to plant daily water use (DWU), the amount of water lost from plant transpiration and substrate evaporation. This is a key concept in scheduling irrigation to conserve water because only water volumes used by the plant and evaporated from the container substrate since the previous irrigation are replaced keeping overwatering to a minimum. An advantage of this approach to irrigation scheduling is that it can be adapted to most types of irrigation systems. The objectives of this experiment were to determine the effects of scheduling irrigation applications based on DWU on irrigation volume, plant growth, substrate soluble salt accumulation, runoff, and nutrient loss compared with a conventional irrigation rate.

\section{Materials and Methods}

Site. The experiment was conducted at the Michigan State University Horticulture Teaching and Research Center (HTRC), Holt, MI. The HTRC is at latitude $42.7^{\circ} \mathrm{N}$, longitude $84.5^{\circ} \mathrm{E}$, and elevation $264 \mathrm{~m}$. Plants were grown on $3 \mathrm{~m} \times 6$-m nursery production areas designed to collect runoff from the production surface. Production areas were oriented east to west on the long axis. The surface was lined with 6-mil polypropylene plastic and covered with a landscape fabric. Production areas slope toward the center and west end to allow runoff collection in an excavated reservoir. Collection reservoirs consisted of a wooden frame lined with a polypropylene pond liner. The 12 production areas used were separated by $3.7 \mathrm{~m}$ to minimize effects of irrigation drift. Precipitation was not excluded but was recorded by a Michigan Automated Weather Network (MAWN) weather station located on-site at the HTRC.

Plant material. Deutzia gracilis Sieb. and Zucc. 'Duncan', Kerria japonica (L.) DC. 'Albiflora', Thuja plicata D. Don. 'Atrovirens', and Viburnum dentatum L. 'Ralph Senior' were classified as low water users by Warsaw et al. (2009) in an irrigation 
experiment in 2006. These species were selected for the current study because they could be grouped together based on similar water requirements. The plants from the 2006 experiment were grown for a second season in the same 10.2-L containers under the same irrigation treatments. Plant material was potted up from $5.7-\mathrm{cm}$ potted liners into $10.2-\mathrm{L}$ containers from 6 to 9 Sept. 2005. Container substrate consisted of $85 \%$ pine bark: $15 \%$ peatmoss (vol:vol). Plants were fertilized on 5 June 2006 with $26 \mathrm{~g}$ per container of a $17.0 \mathrm{~N}-3.5 \mathrm{P}-6.6 \mathrm{~K}$ CRF with micronutrients with a nutrient release period at $27{ }^{\circ} \mathrm{C}$ of 4 months (HFI Topdress Special; Harrell's Inc., Lakeland, FL) and on 14 May 2007 with $26 \mathrm{~g}$ per container of a $19.0 \mathrm{~N}-2.2 \mathrm{P}-$ 7.5K CRF with micronutrients with a release period at $27{ }^{\circ} \mathrm{C}$ of 3 to 4 months (HFI Topdress Special; Harrell's Inc.). K. japonica 'Albiflora' plants were pruned to a uniform height in early June before treatment initiation in 2007. All cultural practices were kept identical except irrigation.

Experimental design. Each of the 12 production areas served as an irrigation treatment replicate and the four irrigation treatments were replicated three times. For plant growth index (GI) and PourThru electrical conductivity (EC) measurements, the experiment was a completely randomized design with six subsamples (individual plants) of each species per treatment replicate. Runoff, $\mathrm{NO}_{3}{ }^{-}-\mathrm{N}$, and $\mathrm{PO}_{4}{ }^{3-}-\mathrm{P}$ were collected from each production area and the experiment was analyzed as a completely randomized design with each nursery production area as a treatment replicate. The control treatment of 19 $\mathrm{mm}$ per application was chosen based on a survey of growers in the southeastern United States where growers reported that they normally watered for $\approx 1 \mathrm{~h}$ intending to apply $25 \mathrm{~mm} \cdot \mathrm{d}^{-1}$ of water (Fare et al., 1992) and from a study by Beeson (2006) who used a control treatment of $18 \mathrm{~mm} \cdot \mathrm{d}^{-1}$ to irrigate 11.4-L container-grown landscape shrubs. In the current study, each plant was irrigated with the same irrigation treatment as the previous year so that growth response after 2 years under the same irrigation treatments could be evaluated. Irrigation treatments were: 1) a control irrigation rate of $19 \mathrm{~mm}$ (1.07 L per container) per application (abbreviated as control); 2) irrigation scheduled to replace $100 \%$ DWU per application (100DWU); 3) irrigation alternating every other application with $100 \%$ replacement of DWU and 75\% DWU the following application (100-75); and 4) irrigation scheduled on a three-application cycle replacing 100\% DWU followed by two applications replacing 75\% DWU (100-75-75). Irrigation applications were separated by at least $24 \mathrm{~h}$ and were applied once per day from 8 June (Day 1) through 30 Sept. (Day 115) 2007. Plants of all species were randomly arranged in each treatment replicate in three rows of eight. Plants were spaced $45 \mathrm{~cm}$ on center. Guard plants (26 plants per treatment replicate) in 10.2-L containers were placed around the outside of each treatment replicate to mini- mize edge effects and spaced $45 \mathrm{~cm}$ from experiment plants. Types of guard plants varied within a treatment replicate, but type and order for all treatment replicates were identical.

Daily water use. Daily water use was measured using a ThetaProbe Type ML2x soil moisture sensor connected to a ThetaMeter Hand-Held Readout Unit Type HH1 (Delta-T Devices Ltd., Cambridge, U.K.). The sensing array of rods of the ThetaProbe is comprised of a $60-\mathrm{mm}$ long center rod with three additional $60-\mathrm{mm}$ rods equally spaced from the center rod forming a cylinder with a diameter of $\approx 30 \mathrm{~mm}$ (Delta-Devices Ltd., 1999). Measurement volume is within a 40$\mathrm{mm}$ diameter by 60 - $\mathrm{mm}$ long cylinder $(\approx 750$ $\mathrm{mm}^{3}$ ) surrounding the central rod (DeltaDevices Ltd., 1999). Volumetric moisture content was measured within the top $60 \mathrm{~mm}$ of the substrate surface by inserting the rods perpendicular to the substrate surface. Container height was $245 \mathrm{~mm}$. A substrate-specific calibration was conducted to improve the accuracy of the ThetaProbe as outlined in the ThetaProbe Type ML2x user manual (DeltaDevices Ltd., 1999). When using the substrate-specific calibration, the reported overall error of the ThetaProbe is $\pm 0.01 \mathrm{~m}^{3} \cdot \mathrm{m}^{-3}$ (Delta-Devices Ltd., 1999). Sampling errors are typically approximately $\pm 0.04 \mathrm{~m}^{3} \cdot \mathrm{m}^{-3}$ but may be as high as $\pm 0.1 \mathrm{~m}^{3} \cdot \mathrm{m}^{-3}$ depending on the number of samples taken, substrate variability, and insertion errors (Delta-Devices Ltd., 1999). Substrate volumetric moisture content was measured $1 \mathrm{~h}$ after irrigation and at $24 \mathrm{~h}$ later before the next irrigation. Measurements of DWU were taken during 24-h periods without precipitation. The percent difference in volumetric moisture content was multiplied by the average volume of container substrate $(9.7 \mathrm{~L})$ to determine the volume of water lost. Irrigation rate of the overhead system was measured before the beginning of the experiment using eight rain gauges randomly placed throughout an irrigation zone to collect water for $30 \mathrm{~min}$. The irrigation cycle was repeated with the eight rain gauges in different locations for a total of 16 measurements. Irrigation rates from three of the 12 production areas were measured and the average irrigation rate was $0.28 \mathrm{~mm} \cdot \mathrm{min}^{-1}$ $\left(17 \mathrm{~mm} \cdot \mathrm{h}^{-1}\right)$.

Irrigation applications. Irrigation applications were scheduled with a Rain Bird ESP-12LX Plus controller (Rain Bird Corporation, Azusa/Glendora, CA). Each treatment replicate was controlled by a solenoid valve. Irrigation was applied through six Toro 570 Shrub Spray Sprinklers (The Toro Company, Riverside, CA) mounted on $1.3-\mathrm{cm}$ diameter risers at a height of $0.66 \mathrm{~m}$. Emitter layout consisted of two $180^{\circ}$ emitters and four $90^{\circ}$ emitters per treatment replicate all with $2.44-\mathrm{m}$ radius distance of throw. Emitters were spaced $2.44 \mathrm{~m}$ apart in two rows of three with four $90^{\circ}$ emitters on the corners and two $180^{\circ}$ emitters on the edges to provide head-to-head coverage. All irrigation was directed into the block. Distribution uniformity of each nursery production bed was adjusted to 0.80 or greater during a period without wind. Irrigation applications were scheduled to apply the correct volume based on irrigation rate and container surface area assuming 100\% canopy penetration without wind and canopy affects. Irrigation treatments based on DWU were applied at the volume corresponding to the species with the highest mean DWU from control production areas (18 plants) on each measurement day to avoid underwatering any species. Irrigation was initiated between $0700 \mathrm{HR} 0800 \mathrm{HR}$.

Plant response to irrigation treatments. Effect of irrigation volume on plant growth and container substrate soluble salt levels was determined by measuring growth index and leachate EC. Plant growth in the current experiment represents the second season of growth under the same irrigation treatments. Plant GI was calculated every 2 to 4 weeks during the experiment. Growth index was calculated as [(plant width $\mathrm{A}+$ plant width perpendicular to width $\mathrm{A}+$ plant height)/3]. Plant width A was the widest plant width on an east to west axis, plant width perpendicular to plant width A was the widest plant width measured on a north to south axis, and plant height was measured from the container rim.

Knox (1989) used the increase in GI per liter of water consumed as an estimate of water use efficiency for five species of container-grown woody landscape plants. Using a similar calculation, plant water use efficiency (WUE) of each species under the four irrigation treatments in the current study was estimated by dividing the GI increase (GII; measured as the difference in final and initial GI) during the experiment by total water applied (irrigation plus precipitation; $\mathrm{L} /$ container).

Leachate EC was measured with a Horiba Cardy Twin EC Meter (Spectrum Technologies, Inc., Plainfield, IL) using the PourThru extraction procedure as described by Yeager (2003). PourThru EC was measured from two plants of each species within each treatment replicate monthly during the experiment.

Runoff collection. Runoff from each production bed was collected $2 \mathrm{~d}$ per month. Runoff was collected when the three DWU treatments were at $100 \% \mathrm{DWU}$ and the other day when the 100-75 treatment was at $75 \%$ DWU and the 100-75-75 treatment was on the second day of $75 \%$ DWU. Runoff was collected by pumping the runoff out of the collection reservoir into a container to measure the volume $0.5 \mathrm{~h}$ after irrigation ended.

Water samples were collected from runoff in each reservoir to determine $\mathrm{NO}_{3}{ }^{-} \mathrm{N}$ and $\mathrm{PO}_{4}{ }^{3-}-\mathrm{P}$ concentrations for each treatment. Samples were stored at $3{ }^{\circ} \mathrm{C}$ until analysis. Analysis of runoff water for $\mathrm{NO}_{3}{ }^{-} \mathrm{N}$ and $\mathrm{PO}_{4}{ }^{3-}-\mathrm{P}$ content was conducted at the Michigan State University Soil Testing Laboratory (A81 Plant \& Soil Sciences Building, Michigan State University, East Lansing, MI) using the cadmium reduction method for $\mathrm{NO}_{3}{ }^{-} \mathrm{N}$ analysis (Brown, 1998) and the Bray and Kurtz P-1 Test for $\mathrm{PO}_{4}{ }^{3-}-\mathrm{P}$ analysis (Brown, 1998). 
Statistical analysis. Data for each species were analyzed separately except for WUE and average irrigation applied per container. Growth index and EC data were analyzed as repeated measures using the PROC MIXED procedure of Statistical Analysis Software (SAS Version 9.1; SAS Institute, Cary, NC). When significant at the 0.05 level, treatment means on each measurement day were separated using a $t$ test in the PDIFF option of the LSMEANS statement and the SLICING option of PROC MIXED ( $\alpha=$ $0.05)$. Average irrigation applied per container, WUE, runoff volume, $\mathrm{NO}_{3}{ }^{-} \mathrm{N}$, and $\mathrm{PO}_{4}{ }^{3-}-\mathrm{P}$ data were subjected to analysis of variance using PROC GLM procedure of SAS (SAS Version 9.1; SAS Institute) and when significant, means were separated using Tukey's honestly significance test at the 0.05 level.

Table 1. Average water applied and total water applied from 8 June through 30 Sept. 2007 (115 d) for Deutzia gracilis 'Duncan', Kerria japonica 'Albiflora', Thuja plicata 'Atrovirens', and Viburnum dentatum 'Ralph Senior' grown in 10.2-L containers under four irrigation treatments.

\begin{tabular}{lcc}
\hline & $\begin{array}{c}\text { Avg water } \\
\text { applied per } \\
\text { container per } \\
\text { application }(\mathrm{L})^{\mathrm{y}}\end{array}$ & $\begin{array}{c}\text { Total water } \\
\text { applied per } \\
\text { container }(\mathrm{L})\end{array}$ \\
Treatment $^{\mathrm{z}}$ & $1.07 \mathrm{a}$ & 123.1 \\
\hline Control & $0.72 \mathrm{~b}$ & 82.8 \\
100DWU & $0.63 \mathrm{c}$ & 72.4 \\
$100-75$ & $0.60 \mathrm{c}$ & 69.0 \\
\hline
\end{tabular}

${ }^{\mathrm{z}}$ Control $=19 \mathrm{~mm}(1.07 \mathrm{~L}$ per container $)$ per application; 100DWU $=100 \%$ daily water use (DWU) per application; 100-75 = two-application cycle with $100 \%$ DWU first application and 75\% DWU second application; and 100-75-75 = three-application cycle $100 \%$ DWU the first application followed by two applications of $75 \%$ DWU. DWU volume applied $=$ highest DWU of the four species on each measurement date. Irrigation applications separated by at least $24 \mathrm{~h}$. ${ }^{y}$ Means separation using Tukey's test $(\alpha=0.05)$, $\mathrm{n}=115$.

\section{Results and Discussion}

Water use. During the 115-d experiment, the control irrigation rate of $19 \mathrm{~mm}(1.07$ $\mathrm{L}$ per container) per application resulted in a total application of $2200 \mathrm{~mm}(123 \mathrm{~L}$ per container) of water (Table 1). Rainfall during this period was $250 \mathrm{~mm}$ and added $14 \mathrm{~L}$ per container (Fig. 1). Irrigation was not applied when rainfall exceeded $20 \mathrm{~mm}$ during a $24-\mathrm{h}$ period, which occurred four times during the experiment. Average water amounts applied per application for the 100DWU, 100-75, and $100-75-75$ treatments were $33 \%, 41 \%$, and $44 \%$, respectively, lower than the control, and the average amounts of water applied per application for the 100-75 and 100-75-75 treatments were lower than the 100DWU treatment (Table 1). These results were similar to the 2006 irrigation experiment using the same plants (Warsaw et al., 2009), but reductions in water applied by the three DWU treatments compared with the control were greater in 2006 than in 2007 with $65 \%$ to $75 \%$ less water applied compared with the control depending on DWU treatment and species in 2006.

Water use of the four species was generally higher in 2007 than in 2006 (Fig. 2A-D; Warsaw et al., 2009). Averaged across all days of the experiment, DWU in 2006 and 2007 were 0.3 and $0.61 \mathrm{~L}$ per container for D. gracilis 'Duncan', 0.37 and $0.62 \mathrm{~L}$ per container for $K$. japonica 'Albiflora', 0.33 and $0.38 \mathrm{~L}$ per container for $T$. plicata 'Atrovirens', and 0.31 and $0.59 \mathrm{~L}$ per container for $V$. dentatum 'Ralph Senior'. Higher DWU in 2007 compared with 2006 was likely the result of higher evaporative demand in 2007. On DWU measurement days in 2006 and 2007, reference potential evapotranspiration from an on-site MAWN weather station averaged $3.7 \mathrm{~mm}$ and $4.1 \mathrm{~mm}$.

Daily water use peaked in late July and early August with the highest DWU of all species on 8 Aug. 2007 (Day 62; Fig. 2A-D).

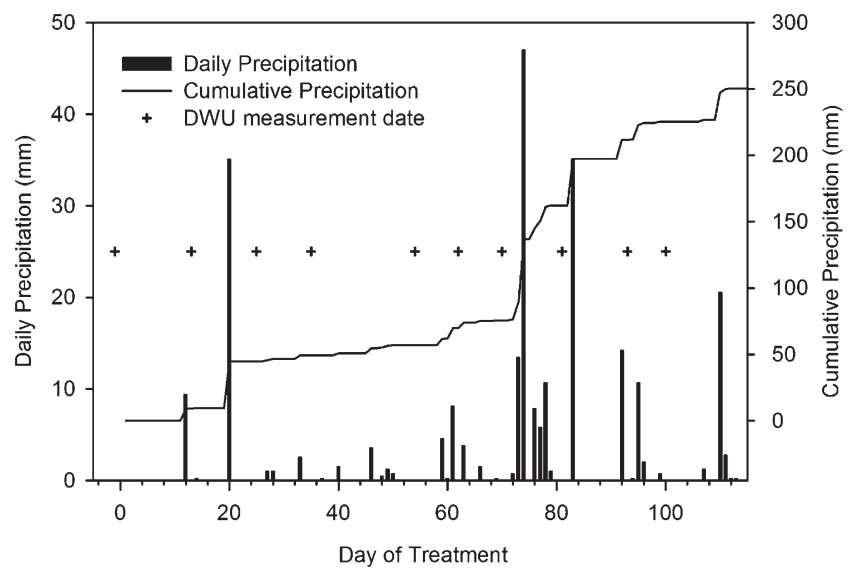

Fig. 1. Daily (bars) and cumulative precipitation (line) from 8 June (Day 1) to 30 Sept. (Day 115$) 2007$. Crosshairs indicate dates of daily water use measurement. Data recorded on site at the Michigan State Horticultural Teaching and Research Center by a Michigan Automated Weather Network weather station.
Average DWU was higher than the control only on 8 Aug. for D. gracilis 'Duncan' and $V$. dentatum 'Ralph Senior' both with DWU values of $22 \mathrm{~mm}$ (Figs. 2A and D). Lowest DWU was recorded on 12 July (Day 35) for D. gracilis 'Duncan', K. japonica 'Albiflora', and T. plicata 'Atrovirens' and 20 June (Day 13) for $V$. dentatum 'Ralph Senior' (Fig. 2AD). Daily water use pattern for the species in the current experiment was similar to that of 10 species of container-grown woody ornamentals in an experiment using the same irrigation treatments that was conducted during the same time period (Warsaw et al., 2009).

Growth index. Final GI measurements of plants irrigated according to DWU were the same or greater compared with the control for all species in 2007. At the end of the 2006 experiment for D. gracilis 'Duncan', GI of the 100DWU treatment was greater than the 100-75 and control treatments, and the 100 75-75 treatment was also greater than the control (Warsaw et al., 2009), but as a result of winter dieback, there were no differences in GI when treatments were initiated in 2007. In 2007, differences in GI of D. gracilis 'Duncan' were first seen on Day 55 in which GI of the 100 DWU treatment was greatest among treatments (Fig. 2A). Final GI (Day 109) of the 100DWU treatment was greater than the 100-75 and control treatments, the same as the final GI response in 2006 (Fig. 2A; Warsaw et al., 2009). During 2006, irrigation did not affect GI of $K$. japonica 'Albiflora' (Warsaw et al., 2009). Plants were pruned before treatment initiation in 2007. During 2007, differences in GI of $K$. japonica 'Albiflora' occurred on the same days as D. gracilis 'Duncan' (Fig. 2B). Effect of irrigation volume on GI of $K$. japonica 'Albiflora' on Day 55 until the end of the experiment was the same with GI of all DWU treatments greater than the control.

In 2007 for T. plicata 'Atrovirens', GI of the 100DWU treatment was higher than the control on each measurement day (Fig. 2C). Differences in GI on the first measurement day were the result of irrigation effects from the 2006 growing season in which final GI of the 100DWU treatment was greater than the 100-75 and control treatments, and GI of the 100-75-75 treatment was greater than the control (Fig. 2C; Warsaw et al., 2009). GI response to irrigation treatment by the final measurement day in 2007 for T. plicata 'Atrovirens' was the same for $K$. japonica 'Albiflora' with GI of all DWU treatments greater than the control (Fig. 2B-C).

There was no irrigation effect on GI of $V$. dentatum 'Ralph Senior' during 2006 (Warsaw et al., 2009) or 2007, although growth of plants in the control treatment did appear to decrease relative to other treatments on the last 3 measurement days in 2007 (Fig. 2D). By the end of the experiment, notable foliage discoloration and yellowing, likely representing nutrient deficiencies, occurred in the control treatment for all species except D. gracilis 'Duncan'. After the 2006 experiment, the only species that exhibited chlorosis was $V$. dentatum 'Ralph Senior', although 


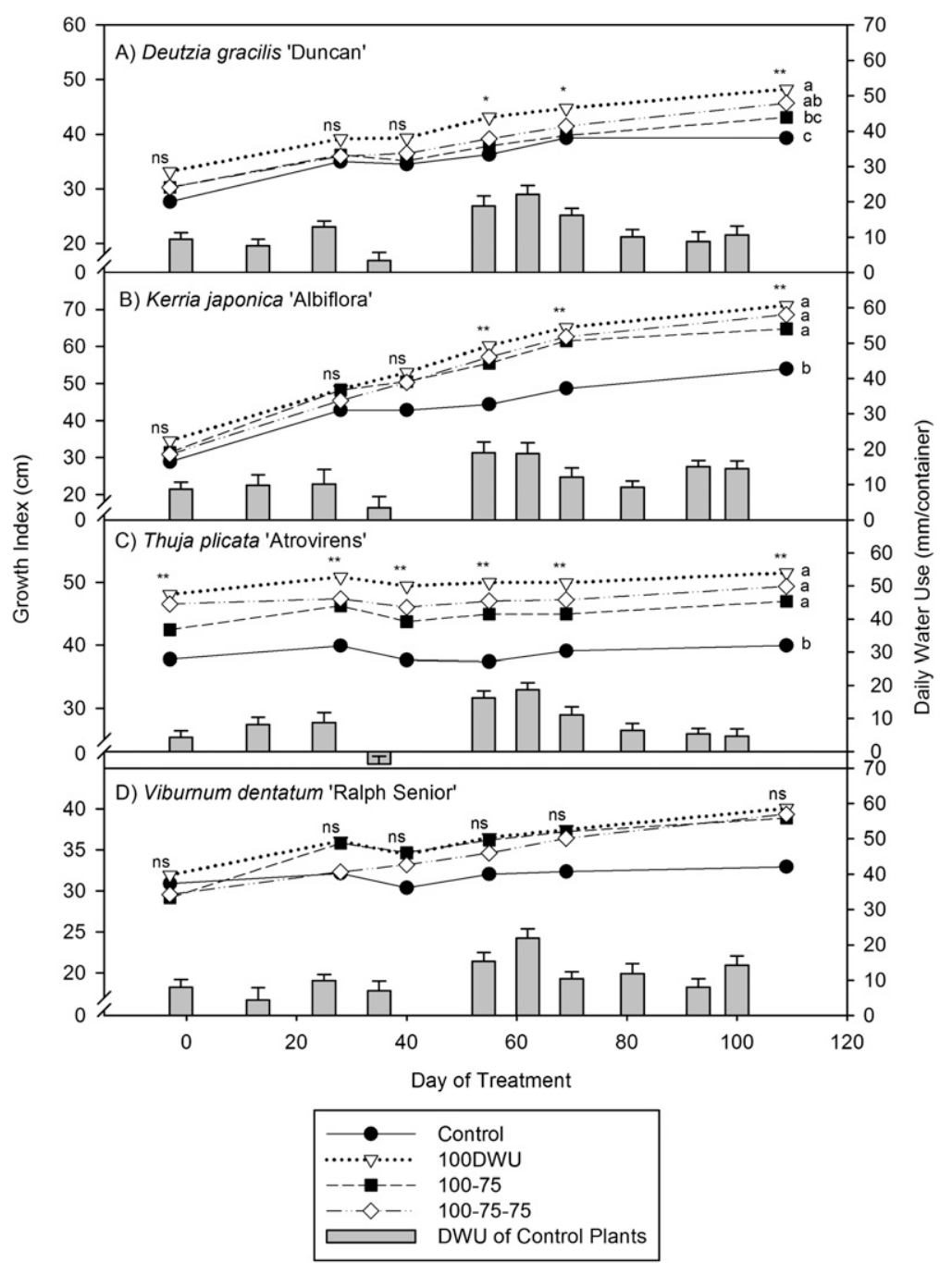

Fig. 2. Daily water use (DWU; bars) and growth index (GI; lines) of four container-grown woody ornamentals under four irrigation treatments applied from 8 June to 30 Sept. 2007. Left y axis corresponds to GI and scale varies depending on species. Right y axis corresponds to DWU. Day $0=7$ June 2007. Error bars for DWU correspond to the SE of the mean of DWU measurement from 18 plants of each species from the control treatment. Irrigation treatments: Control $=19 \mathrm{~mm}$ per application; $100 \mathrm{DWU}=100 \%$ daily water use (DWU) per application; 100-75 = two-application cycle with $100 \%$ DWU first application and 75\% DWU second application; and 100-75-75= three-application cycle $100 \%$ DWU the first application followed by two applications of $75 \%$ DWU. Irrigation applications separated by at least $24 \mathrm{~h}$. For each species, when significant at the 0.05 level, GI treatment means on each day were separated using a $t$ test. NS, ${ }^{*}, * * * * *=$ Nonsignificant or significant at $P \leq 0.05,0.01$, or 0.001 , respectively. Means separation for final GI are shown when significant and for each species, treatment means with the same letters are not significantly different. $\mathrm{n}=18$.

there were no differences in plant growth among treatments.

Final GI of all species under the most restrictive irrigation treatment $(100-75-75)$ did not differ from the GI of plants irrigated according to $100 \%$ DWU. This suggests that the 100-75 and 100-75-75 treatments did not result in water deficits that restricted plant growth despite total water applications of $12 \%$ and $16 \%$, respectively, less than the 100DWU treatment. Additionally, because DWU irrigation volumes were applied at the rate corresponding to the species with the highest mean DWU on each measurement date, species with lower DWU received irrigation in excess of their DWU.

Other studies have also reported substantial reductions in irrigation with minimum leaf number, leaf area, or root area. These studies along with the current study document the adaptability of plants to grow at a wide range of irrigation volumes and the ability of water-conserving irrigation schedules to significantly reduce irrigation inputs with minimal to no effects on growth.

Water use efficiency. Among species, $K$. japonica 'Albiflora' used water the most efficiently in all treatments, whereas T. plicata 'Atrovirens' and $V$. dentatum 'Ralph Senior' generally had the lowest WUE among species in all treatments (Table 2). Because the amount of water applied was the same for each species in this experiment, differences in WUE among species were the result of differences in growth.

For $D$. gracilis 'Duncan', irrigation did not affect GII, but plants in the 100-75-75 treatment used water more efficiently than plants in the control treatment (Table 2). For $K$. japonica 'Albiflora', the GII and WUE of the control were lowest among treatments, whereas the WUE of the 100DWU treatment was lower than the 100-75-75 treatment. Growth index increase of $T$. plicata 'Atrovirens' was unaffected by irrigation volume and WUE of the 100-75 treatment was higher than the control. For $V$. dentatum 'Ralph Senior' GII of the 100-75-75 and 100-75 treatments were higher than the control and plants in the control had the lowest WUE among treatments. Our estimates of higher WUE under lower irrigation volumes agree with those of Tyler et al. (1996) who reported irrigation use efficiency of Cotoneaster dammeri 'Skogholm' under a low LF ( 0.0 to 0.2 ) was $29 \%$ greater than a high LF (0.4 to 0.6$)$. The lower WUE of plants in the control treatment and the DWU values that were lower than control irrigation volumes show that irrigation applied to the control was in excess of plant demand. Excess irrigation applied to the control likely led to the lower final GI of control plants of $D$. gracilis 'Duncan', $K$. japonica 'Albiflora', and T. plicata 'Atrovirens' as a result of excess leaching of nutrients and decreased substrate aeration. Drew (1983) reported that near saturated conditions that limit substrate aeration can reduce root and shoot growth and reduce root respiration.

Electrical conductivity. A concern when scheduling irrigation at or below DWU is that leaching fractions will be close to or below zero and may cause soluble salts in container substrates to accumulate to plant-damaging levels if precipitation or a periodic increase in irrigation to flush excess salts from the substrate does not occur. EC values were highest in June (Day 15) for all treatments and species likely as a result of soluble salt buildup during the winter when irrigation was not applied (Fig. 3A-D). After measurement in June, EC values during the rest of the experiment were between 0.35 and 0.67 $\mathrm{dS} \cdot \mathrm{m}^{-1}$ (Fig. 3A-D). These values were within or slightly above the recommended range of 0.2 to $0.5 \mathrm{dS} \cdot \mathrm{m}^{-1}$ for containergrown woody ornamentals in pine bark substrates fertilized with only a CRF (Southern Nursery Association, 2007). 
Table 2. Estimated water use efficiency (WUE) of four container-grown woody ornamentals under four irrigation regimes from 8 June to 30 Sept. 2007. ${ }^{\mathrm{z}}$

\begin{tabular}{|c|c|c|c|c|}
\hline \multirow[b]{2}{*}{ Taxa } & \multicolumn{4}{|c|}{ Treatment $^{y}$} \\
\hline & $\overline{\text { Control }}$ & 100DWU & $100-75$ & $100-75-75$ \\
\hline Total water applied ${ }^{x}$ & 137 & 96 & 86 & 83 \\
\hline \multicolumn{5}{|l|}{ Deutzia gracilis Duncan } \\
\hline Increase in GI $(\mathrm{cm})$ & $11.7 \mathrm{a}^{\mathrm{w}}$ & $15.1 \mathrm{a}$ & $12.8 \mathrm{a}$ & $15.4 \mathrm{a}$ \\
\hline WUE & $0.09 \mathrm{bB}^{\mathrm{v}}$ & $0.16 \mathrm{abB}$ & $0.15 \mathrm{abB}$ & $0.19 \mathrm{aB}$ \\
\hline \multicolumn{5}{|c|}{ Kerria japonica Albiflora } \\
\hline Increase in GI $(\mathrm{cm})$ & $24.3 \mathrm{~b}$ & $36.0 \mathrm{a}$ & $33.4 \mathrm{a}$ & $37.7 \mathrm{a}$ \\
\hline WUE & $0.18 \mathrm{cA}$ & $0.37 \mathrm{bA}$ & $0.39 \mathrm{abA}$ & $0.45 \mathrm{aA}$ \\
\hline \multicolumn{5}{|l|}{ Thuja plicata Atrovirens } \\
\hline Increase in GI $(\mathrm{cm})$ & $2.2 \mathrm{a}$ & $3.4 \mathrm{a}$ & $4.5 \mathrm{a}$ & $2.8 \mathrm{a}$ \\
\hline WUE & $0.02 \mathrm{bC}$ & $0.04 \mathrm{abC}$ & $0.05 \mathrm{aC}$ & $0.03 \mathrm{abC}$ \\
\hline \multicolumn{5}{|c|}{ Viburnum dentatum Ralph Senior } \\
\hline Increase in GI $(\mathrm{cm})$ & $1.6 \mathrm{~b}$ & $8.1 \mathrm{ab}$ & $9.7 \mathrm{a}$ & $9.8 \mathrm{a}$ \\
\hline WUE & $0.01 \mathrm{bC}$ & $0.08 \mathrm{aBC}$ & $0.11 \mathrm{aBC}$ & $0.12 \mathrm{aB}$ \\
\hline
\end{tabular}

${ }^{\mathrm{z}}$ WUE estimated as increase in growth index $(\mathrm{cm})$ per liter of water applied per container (irrigation + precipitation).

${ }^{\mathrm{y}}$ Control $=19 \mathrm{~mm}$ per application; $100 \mathrm{DWU}=100 \%$ daily water use (DWU) per application; $100-75=$ two-application cycle with 100\% DWU first application and 75\% DWU second application; and 100-75$75=$ three-application cycle with 100\% DWU the first application followed by two applications of $75 \%$ DWU. DWU treatments applied at rate corresponding to species with the highest DWU. Irrigation applications separated by at least $24 \mathrm{~h}$.

${ }^{\mathrm{x}}$ Liters per container from 8 June to 30 Sept. 2007.

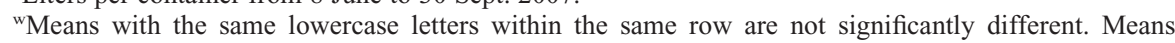
separation with Tukey's test $(\alpha=0.05)$.

${ }^{v}$ Means with the same uppercase letters within the same column are not significantly different. Means separation with Tukey's test $(\alpha=0.05)$.

$\mathrm{GI}=$ growth index.

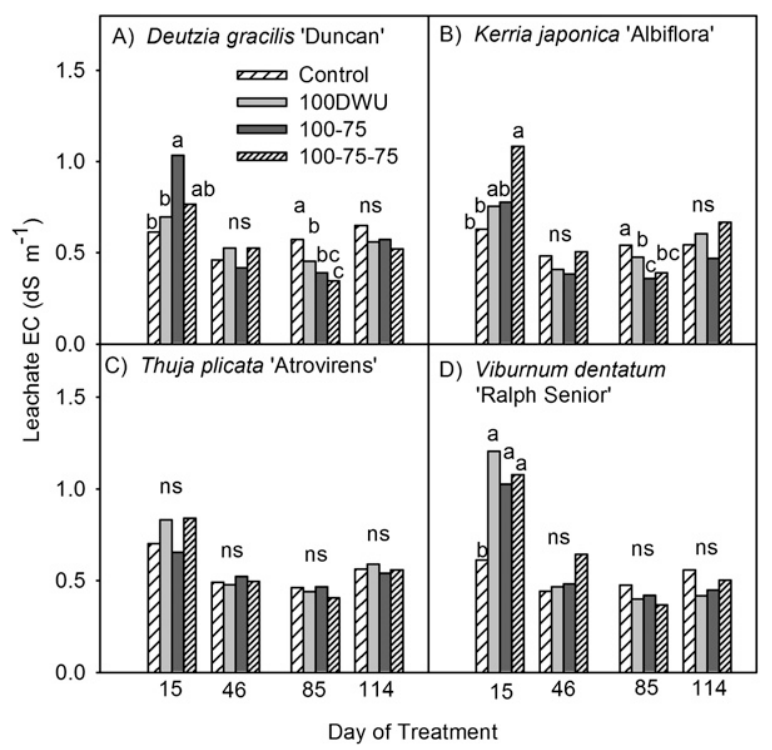

Fig. 3. PourThru leachate electrical conductivity (EC) of four container-grown woody ornamentals under four irrigation treatments applied from 8 June (Day 1) to 31 Sept. (Day 115) 2007. Means separated by $t$ test $(\alpha=0.05 ; \mathrm{n}=6)$. Irrigation treatments: Control $=19 \mathrm{~mm}$ per application; $100 \mathrm{DWU}=100 \%$ daily water use (DWU) per application; 100-75 = two-application cycle with $100 \%$ DWU first application and $75 \%$ DWU second application; and 100-75-75= three-application cycle with $100 \%$ DWU the first application followed by two applications of $75 \%$ DWU. Irrigation applications separated by at least $24 \mathrm{~h}$. DWU treatments applied at rate corresponding to species with the highest DWU.

On Day 15, EC of the control treatment was lower or not different from EC of the three DWU treatments for all species with individual species responses shown in Figure 3A-D. However, there were no other differences among treatments for any species except D. gracilis 'Duncan' and K. japonica 'Albiflora' on Day 85 when for both species, leachate $\mathrm{EC}$ of the control was highest among treatments (Fig. 3A-B). Although differences strate solution resulting in lower leachate EC values in the DWU treatments compared with the control. Additionally, higher irrigation volumes in the control treatment would lead to greater nutrient leaching from containers. The lack of irrigation effect on leachate EC among treatments of T. plicata 'Atrovirens' on all measurement days may be partly the result of the small increase in GI that occurred during the study (Figs. 2C and 3C). Bilderback et al. (1999) investigated whether weekly adjustments of irrigation volumes based on EC could reduce excess and deficient nutrient levels in containers and lengthen CRF longevity. Bilderback et al. (1999) reported EC of container-grown Cotoneaster dammeri 'Skogholm' in 3.8-L containers among all fertilization rates did not exceed the target concentration of $1.75 \mathrm{dS} \cdot \mathrm{m}^{-1}$ that was required to increase the irrigation volume by $15 \%$ the next week and that EC levels were rarely above $0.5 \mathrm{dS} \cdot \mathrm{m}^{-1}$ during the $152-\mathrm{d}$ study. Like the current study, precipitation was not excluded and Bilderback et al. (1999) concluded that rainfall lowered EC and negated the influence of irrigation volume on container EC. In climates where precipitation is frequent and sufficient enough to periodically leach excess salts from substrates, EC is less likely to accumulate above recommended ranges. However, this should not preclude normal monitoring of EC and where leaching rains do not occur or during periods of drought, EC should be more closely monitored to ensure soluble salts remain within acceptable ranges.

Runoff volume. Irrigation applied at $100 \%$ DWU and $75 \%$ DWU reduced runoff compared with the control treatment on each collection day (Fig. 4). Across all collection days, average daily runoff volumes from production areas irrigated with $100 \%$ and $75 \%$ DWU irrigation volumes were $66 \%$ $\left(7.5 \mathrm{~L} \cdot \mathrm{m}^{-2} \cdot \mathrm{d}^{-1}\right)$ and $79 \%\left(9.0 \mathrm{~L} \cdot \mathrm{ha}^{-2} \cdot \mathrm{d}^{-1}\right)$ lower than the control runoff volume of $11.4 \mathrm{~L} \cdot \mathrm{m}^{-2} \cdot \mathrm{d}^{-1}$. Average daily irrigation volumes applied at $100 \%$ and $75 \%$ DWU were $45 \%$ and $59 \%$ less, respectively, than control irrigation volume across all collection days (Fig. 4). Percent irrigation applied captured as runoff for the control, $100 \%$ DWU, and $75 \%$ DWU irrigation volumes ranged from $31 \%$ to $74 \%, 14 \%$ to $63 \%$, and $18 \%$ to $51 \%$, respectively, depending on collection day. When averaged across all collection days, percent irrigation captured as runoff for the control, $100 \%$ DWU, and 75\% DWU irrigation volumes were $60 \%, 37 \%$, and $32 \%$, respectively. Lower percentages of irrigation captured as runoff from the $100 \%$ and $75 \%$ DWU irrigation volumes compared with the control likely resulted from lower irrigation volumes applied to containers receiving DWU irrigation volumes compared with the control. Furthermore, containers receiving DWU irrigation volumes likely had lower preirrigation substrate moisture levels compared with the control that allowed a higher percentage of applied water to be retained in the container substrate.

The lower runoff volumes resulting from lower irrigation volumes in this study are 


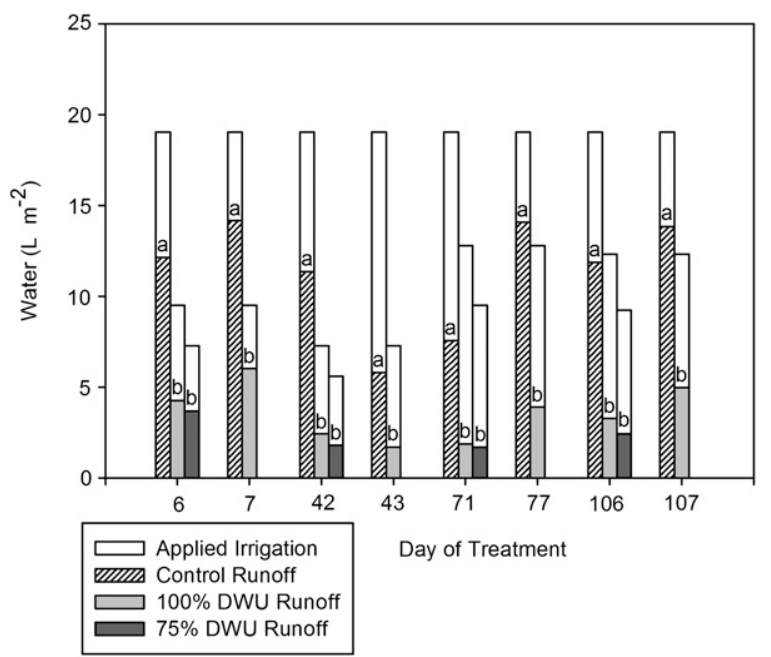

Fig. 4. Daily irrigation applied and collected runoff from $3 \mathrm{~m} \times 6-\mathrm{m}$ production areas for 10.2-L containergrown woody ornamentals receiving a control irrigation of $19 \mathrm{~mm}\left(19 \mathrm{~L} \cdot \mathrm{m}^{-2}\right)$ per application, $100 \%$ daily water use (DWU) per application, or 75\% DWU per application from 8 June (Day 1) to 30 Sept. (Day 115) 2007. On Days 7, 43, 77, and 107, all DWU treatments received 100\% DWU. Error bars represent SE of treatment means. Means separation within each day by Tukey's test $(\alpha=0.05)$.

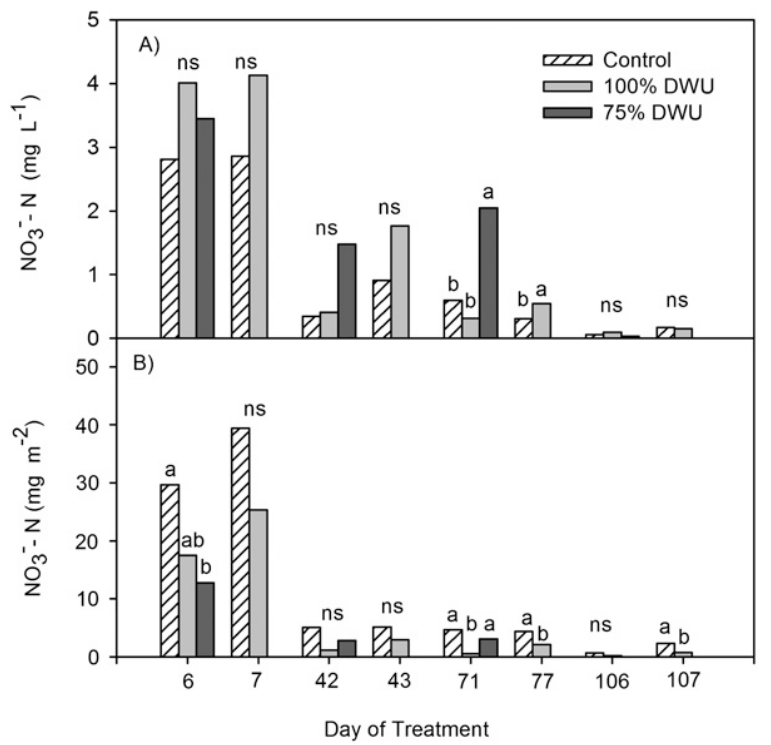

Fig. 5. $\mathrm{NO}_{3}{ }^{-} \mathrm{N}$ concentration (A) and quantity (B) in runoff from $3 \mathrm{~m} \times 6-\mathrm{m}$ production areas receiving irrigation as a control of $19 \mathrm{~mm}\left(19 \mathrm{~L} \cdot \mathrm{m}^{-2}\right)$ per application, $100 \%$ daily water use (DWU) per application, or $75 \%$ DWU per application. Day $1=8$ June 2007. On Days 7, 43, 77, and 107, all DWU treatments received $100 \%$ DWU. Means separation by Tukey's test $(\alpha=0.05)$.

consistent with those of Fare et al. (1994) who reported that container leachate and total effluent were reduced by $\approx 50 \%$ and $28 \%$ when $8 \mathrm{~mm}$ of irrigation was applied compared with $13 \mathrm{~mm}$ for Ilex crenata 'Compacta' grown in 2.3-L containers. Additionally, Karam and Niemiera (1994) developed regression models that showed leachate volume increased as preirrigation substrate water content increased and volume of water applied increased for continuous and cyclic overhead irrigation.

Nitrates and phosphates. Runoff $\mathrm{NO}_{3}{ }^{-}-\mathrm{N}$ concentrations for individual production areas of all treatments were less than 5.5 $\mathrm{mg} \cdot \mathrm{L}^{-1}$ on each day sampled except on Day 7 when $\mathrm{NO}_{3}{ }^{-}-\mathrm{N}$ concentration in runoff from one production area in the 100-75-75 irrigation treatment irrigated at $100 \%$ DWU was $7.55 \mathrm{mg} \cdot \mathrm{L}^{-1}$. These concentrations were below the $10 \mathrm{mg} \cdot \mathrm{L}^{-1}$ maximum contamination level established by the U.S. Environmental Protection Agency National Drinking Water Standards (U.S. Environmental Protection Agency, 2003). Runoff $\mathrm{NO}_{3}{ }^{-} \mathrm{N}$ concentration of the control and 100\% DWU volumes were highest on Day 7 at $4.13 \mathrm{mg} \cdot \mathrm{L}^{-1}$ and $2.86 \mathrm{mg} \cdot \mathrm{L}^{-1}$ (Fig. 5A). Runoff from the $75 \%$ DWU irrigation volume was not collected on Day 7 because all DWU treatments received $100 \%$ DWU. Runoff $\mathrm{NO}_{3}{ }^{-}-\mathrm{N}$ concentration of the $75 \%$ DWU volume was highest on Day 6 at $3.45 \mathrm{mg} \cdot \mathrm{L}^{-1}$ (Fig. 5A). On Day $71, \mathrm{NO}_{3}{ }^{-}-\mathrm{N}$ concentrations in runoff from the $75 \%$ DWU volume were greater than concentrations of the control and $100 \%$ DWU volumes (Fig. 5A). On Day 77, $\mathrm{NO}_{3}{ }^{-}-\mathrm{N}$ concentrations from the $100 \%$ DWU irrigation volume were greater than the control.

Quantities of $\mathrm{NO}_{3}{ }^{-}-\mathrm{N}$ and $\mathrm{PO}_{4}{ }^{3-}-\mathrm{P}$ recovered in runoff were calculated by multiplying concentration $\left(\mathrm{mg} \cdot \mathrm{L}^{-1}\right)$ by volume of runoff collected (L). Quantities of $\mathrm{NO}_{3}{ }^{-}-\mathrm{N}$ collected in runoff were greatest on Day 7 for the control and $100 \%$ DWU irrigation volumes with means of $39.4 \mathrm{mg} \cdot \mathrm{m}^{-2}$ and $25.3 \mathrm{mg} \cdot \mathrm{m}^{-2}$, respectively (Fig. 5B). The $75 \%$ DWU irrigation volume was not sampled on this date. For the $75 \%$ DWU volume, the greatest $\mathrm{NO}_{3}{ }^{-}-\mathrm{N}$ loss was on Day 6 with mean $\mathrm{NO}_{3}{ }^{-} \mathrm{N}$ quantity of $12.8 \mathrm{mg} \cdot \mathrm{m}^{-2}$ (Fig. $5 \mathrm{~B}$ ). Total applied $\mathrm{N}$ was equivalent to $13,700 \mathrm{mg} \cdot \mathrm{m}^{-2}$. Therefore $\mathrm{NO}_{3}{ }^{-}-\mathrm{N}$ losses on Day 7 for the control and $100 \%$ DWU irrigation volumes and on Day 6 for the $75 \%$ irrigation volume were $0.3 \%, 0.2 \%$, and $0.1 \%$ of total applied $\mathrm{N}$, respectively. Lower quantities of $\mathrm{NO}_{3}{ }^{-} \mathrm{N}$ were present in runoff from areas irrigated with the $100 \%$ DWU volume compared with the control on Days 71, 77, and 107 (Fig. 5B). On Day 6, lower quantities of $\mathrm{NO}_{3}{ }^{-}-\mathrm{N}$ were present in runoff from areas irrigated with the $75 \%$ DWU volume compared with the control. Over all collection days, the $100 \%$ DWU and $75 \%$ DWU irrigation volumes reduced $\mathrm{NO}_{3}{ }^{-} \mathrm{N}$ quantities in runoff by an average of $38 \%\left(4.3 \mathrm{mg} \cdot \mathrm{m}^{-2} \cdot \mathrm{d}^{-1}\right)$ and $59 \%$ $\left(6.7 \mathrm{mg} \cdot \mathrm{m}^{-2} \cdot \mathrm{d}^{-1}\right)$, respectively, compared with average losses in the control of 11.4 $\mathrm{mg} \cdot \mathrm{m}^{-2} \cdot \mathrm{d}^{-1}$.

Runoff $\mathrm{PO}_{4}{ }^{3-}-\mathrm{P}$ concentrations for individual production areas of all treatments were less than $1.4 \mathrm{mg} \cdot \mathrm{L}^{-1}$ on each collection day. Peak $\mathrm{PO}_{4}{ }^{3-}-\mathrm{P}$ concentration in runoff coincided with dates of highest $\mathrm{NO}_{3}{ }^{-} \mathrm{N}$ concentration. Concentration of $\mathrm{PO}_{4}{ }^{3-}-\mathrm{P}$ in runoff from the control and $100 \%$ DWU irrigation volumes was highest on Day 7 at $0.70 \mathrm{mg} \cdot \mathrm{L}^{-1}$ and $0.78 \mathrm{mg} \cdot \mathrm{L}^{-1}$, respectively (Fig. 6A). The highest $\mathrm{PO}_{4}^{3-}-\mathrm{P}$ concentration of the $75 \%$ DWU irrigation volume was $0.52 \mathrm{mg} \cdot \mathrm{L}^{-1}$ on Day 6 (Fig. 6A). On Days 77 and 107, $\mathrm{PO}_{4}{ }^{3-}-\mathrm{P}$ concentrations in runoff from areas irrigated with the $100 \%$ DWU volume were greater than the control; 75\% DWU volume was not collected on these days. On Day 106, $\mathrm{PO}_{4}{ }^{3-}-\mathrm{P}$ concentration was greater in runoff collected from areas irrigated with $75 \%$ DWU compared with the control.

Irrigating according to $100 \%$ DWU and $75 \%$ DWU resulted in lower quantities of $\mathrm{PO}_{4}{ }^{3-}-\mathrm{P}$ in runoff compared with the control on Day 6 (Fig. 6B). Additionally, quantity of $\mathrm{PO}_{4}{ }^{3-}-\mathrm{P}$ in runoff from the $100 \%$ DWU irrigation volume was lower compared with the control on Day 7. Similar to $\mathrm{NO}_{3}{ }^{-} \mathrm{N}$ quantities, $\mathrm{PO}_{4}{ }^{3-}-\mathrm{P}$ quantities in runoff from the control and $100 \%$ DWU irrigation volumes were highest on Day 7 with means of $9.0 \mathrm{mg} \cdot \mathrm{m}^{-2}$ and $4.7 \mathrm{mg} \cdot \mathrm{m}^{-2}$, respectively (Fig. 6B). Quantity of $\mathrm{PO}_{4}{ }^{3-}-\mathrm{P}$ in runoff of the $75 \%$ DWU irrigation volume was highest at $1.9 \mathrm{mg} \cdot \mathrm{m}^{-2}$ on Day 6 , the same day as peak $\mathrm{NO}_{3}{ }^{-}-\mathrm{N}$ quantities from the $75 \% \mathrm{DWU}$ volume. Total $\mathrm{P}$ applied was equivalent to 


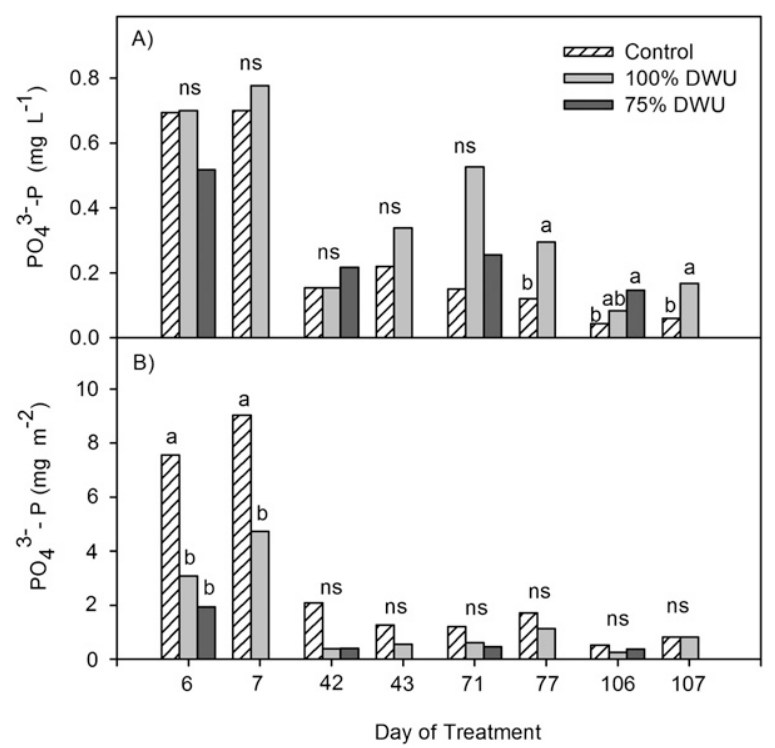

Fig. 6. $\mathrm{PO}_{4}{ }^{3-}-\mathrm{P}$ concentration (A) and quantity (B) in runoff from $3 \mathrm{~m} \times 6-\mathrm{m}$ production areas receiving irrigation as a control of $19 \mathrm{~mm}\left(19 \mathrm{~L} \cdot \mathrm{m}^{-2}\right)$ per application, $100 \%$ daily water use (DWU) per application, or 75\% DWU per application. Day $1=8$ June 2007. On Days 7, 43, 77, and 107, all DWU beds received $100 \%$ DWU. Means separation by Tukey's test $(\alpha=0.05)$.

$1680 \mathrm{mg} \cdot \mathrm{m}^{-2}$. Therefore $\mathrm{PO}_{4}{ }^{3-}-\mathrm{P}$ losses in runoff on Day 7 for the control and $100 \%$ DWU irrigation volume and on Day 6 for the $75 \%$ irrigation volume were $0.5 \%, 0.3 \%$, and $0.1 \%$, respectively, of total applied P. Across all collection days, irrigating at volumes corresponding to $100 \%$ DWU and $75 \%$ DWU reduced $\mathrm{PO}_{4}{ }^{3-}-\mathrm{P}$ quantities in runoff by an average of $46 \%\left(1.4 \mathrm{mg} \cdot \mathrm{m}^{-2} \cdot \mathrm{d}^{-1}\right)$ and $74 \%$ $\left(2.2 \mathrm{mg} \cdot \mathrm{m}^{-2} \cdot \mathrm{d}^{-1}\right)$ compared with average losses in the control of $3.0 \mathrm{mg} \cdot \mathrm{m}^{-2} \cdot \mathrm{d}^{-1}$. On days when $\mathrm{PO}_{4}^{3-}-\mathrm{P}$ concentrations were higher for the $100 \%$ and $75 \%$ irrigation volumes compared with the control, there were no differences in quantities of $\mathrm{PO}_{4}{ }^{3-}-\mathrm{P}$ lost among treatments (Fig. 6A-B). On Days 6 and 7 , there was no difference in $\mathrm{PO}_{4}{ }^{3-}-\mathrm{P}$ concentration among irrigation volumes, but $\mathrm{PO}_{4}{ }^{3-}-\mathrm{P}$ quantities in runoff were greater in the control compared with the $100 \%$ and $75 \%$ irrigation volumes (Fig. 6A-B).

Irrigation at $100 \%$ and $75 \%$ irrigation volumes produced less runoff than the control. Therefore, nutrients leached from $100 \%$ and $75 \%$ irrigation volume containers would not be diluted to the extent as nutrients leached from control containers. These factors explain the higher concentrations but lower quantities of $\mathrm{NO}_{3}{ }^{-}-\mathrm{N}$ and $\mathrm{PO}_{4}{ }^{3-}-\mathrm{P}$ in runoff in the $100 \%$ and $75 \%$ irrigation volumes that occurred on some days during the experiment. However, differences in $\mathrm{NO}_{3}{ }^{-} \mathrm{N}$ and $\mathrm{PO}_{4}{ }^{3-}-\mathrm{P}$ concentrations only occurred on 2 and $3 \mathrm{~d}$ of 8 collection days. On days when there was no difference in concentrations of $\mathrm{NO}_{3}{ }^{-} \mathrm{N}$ and $\mathrm{PO}_{4}{ }^{3-}-\mathrm{P}$ in runoff, increased plant growth and canopy size of experimental and possibly guard plants in production areas irrigated with $100 \%$ and $75 \%$ irrigation volumes could have taken up more nutrients than control plants, thereby offsetting the dilution effect caused by higher amounts of irrigation and runoff in control production areas.
Higher irrigation volumes resulted in greater losses of $\mathrm{NO}_{3}{ }^{-}-\mathrm{N}$ and $\mathrm{PO}_{4}{ }^{3-}-\mathrm{P}$ in the current study because of increased leaching. Several studies have documented an increase in container leachate and nutrient loss with an increase in irrigation volume. Tyler et al. (1996) reported that a low LF of 0.0 to 0.2 reduced irrigation volume and effluent volume by $44 \%$ and $63 \%$ compared with a high LF of 0.4 to 0.6 , and that after $100 \mathrm{~d}$, cumulative losses of $\mathrm{NO}_{3}{ }^{-}-\mathrm{N}$ and $\mathrm{P}$ in effluent were $66 \%$ and $57 \%$ lower, respectively, from the low LF compared with the high LF. Karam and Niemiera (1994) reported that leachate volumes under a water application rate (WAR) of $21 \mathrm{~mm} \cdot \mathrm{h}^{-1}$ resulted in $66 \%$ higher total $\mathrm{N}\left(\mathrm{NO}_{3}{ }^{-}-\mathrm{N}\right.$ and $\left.\mathrm{NH}_{4}{ }^{+}-\mathrm{N}\right)$ leached compared with a lower WAR of $7 \mathrm{~mm} \cdot \mathrm{h}^{-1}$. The study by Karam and Niemiera (1994) cannot be directly compared with the current study, because our treatments were based on irrigation volume, not WAR. However, the study by Karam and Niemiera (1994) does document an increase in nutrient loss with an increase in leachate, which also occurred in the current study. Fare et al. (1994) reported total effluent was reduced by $51 \%$ with a 6-mm irrigation depth compared with an irrigation of $13 \mathrm{~mm}$. With $13 \mathrm{~mm}$ irrigation and a high fertilizer rate, $63 \%$ of the total $\mathrm{N}$ applied was leached as $\mathrm{NO}_{3}^{-}-\mathrm{N}$, and this amount was reduced by $53 \%$ with $6 \mathrm{~mm}$ irrigation. Additionally, under the low fertilizer rate and $13 \mathrm{~mm}$ irrigation, as much as $69 \%$ of total applied $\mathrm{N}$ was leached as $\mathrm{NO}_{3}{ }^{-} \mathrm{N}$, and this amount was reduced by $64 \%$ with $6 \mathrm{~mm}$ irrigation (Fare et al., 1994). Data from these studies showed that greater $\mathrm{NO}_{3}{ }^{-} \mathrm{N}$ losses resulted from greater irrigation and leaching volumes and support the greater $\mathrm{NO}_{3}{ }^{-} \mathrm{N}$ losses that occurred in the current study under higher irrigation and runoff volumes. $K$. japonica 'Albiflora', T. plicata 'Atrovirens', and $V$. dentatum 'Ralph Senior' in control production areas were chlorotic by the end of the experiment. Chlorosis could be from a combination of factors, including nutrient loss from leaching and low substrate aeration from excess water. However, a foliar analysis was not performed and therefore nutrient deficiencies, although likely, could not be confirmed.

\section{Conclusions}

Irrigation scheduling according to the 100DWU, 100-75, and 100-75-75 irrigation treatments reduced total irrigation inputs by $33 \%, 41 \%$, and $44 \%$, respectively, compared with the $123 \mathrm{~L}$ per container applied by the control treatment during the 115-d experiment (8 June through 30 Sept. 2007). During the experiment, soluble salts did not accumulate to damaging levels in containers of any irrigation treatment despite an extended dry period from Day 21 to Day 58 (28 June to 4 Aug.) in which only $12.45 \mathrm{~mm}$ of precipitation occurred and the largest precipitation event was $3.56 \mathrm{~mm}$ on Day 46 (23 July; Fig. 1). Final plant size of all species in the three DWU treatments after two growing seasons under the same irrigation treatments were greater than or equal to the size of control plants, depending on species.

Within each treatment, $K$. japonica 'Albiflora' used water the most efficiently compared with the other three species and T. plicata 'Atrovirens' was consistently among the species with the lowest WUE (Table 2). Average DWU data (Fig. 2) and WUE data (Table 2) of the current study along with that of Knox (1989) shows that water use is influenced by species and seasonal growth pattern. Knowing the DWU and WUE of container-grown woody ornamentals would facilitate more efficient management of water resources by allowing growers to group species with similar DWU and WUE together to minimize overwatering.

In addition to reducing irrigation inputs, irrigating according to DWU substantially reduced runoff and nutrient losses during the experiment. Over all collection dates, irrigation applications at $100 \%$ and $75 \%$ DWU reduced captured runoff by $66 \%$ and $79 \%$, respectively, compared with average control runoff of $11.4 \mathrm{~L} \cdot \mathrm{m}^{-2} \cdot \mathrm{d}^{-1}$. Losses of $\mathrm{NO}_{3}{ }^{-}-\mathrm{N}$ quantities across all collection dates for the $100 \%$ DWU and $75 \%$ DWU irrigation volumes averaged $38 \%$ and $59 \%$ less, respectively, than average control losses of 11.4 $\mathrm{mg} \cdot \mathrm{m}^{-2} \cdot \mathrm{d}^{-1}$. Losses of $\mathrm{PO}_{4}{ }^{3-}-\mathrm{P}$ quantities across all collection dates under the $100 \%$ and $75 \%$ DWU volumes were $46 \%$ and $74 \%$ lower, respectively, than average control losses of $3.0 \mathrm{mg} \cdot \mathrm{m}^{-2} \cdot \mathrm{d}^{-1}$. Research from this experiment showed that lower irrigation volumes reduced nutrient losses and led to increased plant growth by keeping greater quantities of nutrients in the substrate solution for plant absorption. By scheduling irrigation according to DWU, growers cannot only conserve water but reduce runoff and $\mathrm{NO}_{3}{ }^{-} \mathrm{N}$, and $\mathrm{PO}_{4}{ }^{3-}-\mathrm{P}$ losses from containers, thereby 
maximizing fertilizer benefits and minimizing the potential for environmental contamination.

\section{Literature Cited}

Beeson, R.C., Jr. 2006. Relationship of plant growth and actual evapotranspiration to irrigation frequency based on management allowed deficits for container nursery stock. J. Amer. Soc. Hort. Sci. 131:140-148.

Beeson, R.C., Jr., M.A. Arnold, T.E. Bilderback, B. Bolusky, S. Chandler, H.M. Gramling, J.D. Lea-Cox, J.R. Harris, P.J. Klinger, H.M. Mathers, J.M. Ruter, and T.H. Yeager. 2004. Strategic vision of container nursery irrigation in the next ten years. J. Environ. Hort. 22:113-115.

Bilderback, T.E., S.L. Warren, and J.H. Daniels. 1999. Managing irrigation by electrical conductivity. Proc. Int. Sym. Growing Media and Hydroponics. Acta Hort 481:403-408.

Brown, J.R. Revised Jan. 1998. Recommended chemical soil test procedures for the North Central region. North Central Regional Research Publication No. 221:17-20, 21-30.

Delta-Devices Ltd. 1999. ThetaProbe soil moisture sensor. User manual ML2-UM-1.21. Delta-T Devices Ltd., Cambridge, UK.

Drew, M.C. 1983. Plant injury and adaptation to oxygen deficiency in the root environment: A review. Plant Soil 75:179-199.

Fain, G.B., C.H. Gilliam, K.M. Tilt, J.W. Olive, and B. Wallace. 2000. Survey of best manage- ment practices in container production nurseries. J. Environ. Hort. 18:142-144.

Fare, D.C., C.G. Gilliam, and G.J. Keever. 1992. Monitoring irrigation at container nurseries. HortTechnology 2:75-78.

Fare, D.C., C.H. Gilliam, G.J. Keever, and J.W. Olive. 1994. Cyclic irrigation reduces container nitrate-nitrogen concentration. HortScience 29:1514-1517.

Groves, K.M., S.L. Warren, and T.E. Bilderback. 1998. Irrigation volume, application, and controlled-release fertilizers: I. Effect on plant growth and mineral nutrient content in containerized plant production. J. Environ. Hort. 16:176-181.

Karam, N.S. and A.X. Niemiera. 1994. Cyclic sprinkler irrigation and pre-irrigation substrate water content affect water and $\mathrm{N}$ leaching from containers. J. Environ. Hort. 12:198-202.

Knox, G.W. 1989. Water use and average growth index of five species of container grown woody landscape plants. J. Environ. Hort. 7:136-139.

Southern Nursery Association. 2007. Best management practices: Guide for producing nursery crops. 2nd Ed. Southern Nursery Association, Atlanta, GA.

Tyler, H.H., S.L. Warren, and T.E. Bilderback. 1996. Reduced leaching fractions improve irrigation use efficiency and nutrient efficacy. J. Environ. Hort. 14:199-204.

U.S. Environmental Protection Agency. 2003. EPA national drinking water standards. Office of
Water (4604M). EPA 816-F-03-016. 4 Mar. 2009. <http://www.epa.gov/safewater/consumer/ $\mathrm{pdf} / \mathrm{mcl} . \mathrm{pdf}>$.

Warren, S.L., T.E. Bilderback, and H.H. Tyler. 1995. Efficacy of three nitrogen and phosphorous sources in container-grown azalea production. J. Environ. Hort. 13:147-151.

Warsaw, A.L., R.T. Fernandez, B.M. Cregg, and J.A. Andresen. 2009. Water conservation, growth, and water use efficiency of containergrown woody ornamentals irrigated based on daily water use. HortScience 44:1308-1318.

Weatherspoon, D.M. and C.C. Harrell. 1980. Evaluation of drip irrigation for container production of woody landscape plants. HortScience 15:488-489.

Welsh, D.F., J.M. Zajicek, and C.G. Lyons, Jr. 1991. Effect of seasons and irrigation regimes on plant growth and water-use of containergrown Photina $\times$ fraseri. J. Environ. Hort. 9:7982.

Yeager, T. and G. Cashion. 1993. Controlledrelease fertilizers affect nitrate nitrogen runoff from container plants. HortTechnology 3:174 177.

Yeager, T.H. 2003. Implementation guide for container-grown plant interim Measure. EDIS Document ENH-895. Environmental Horticulture Department, Florida Cooperative Extension Service, Institute of Food and Agricultural Sciences, University of Florida. 23 Jan. 2008. $<$ http://edis.ifas.ufl.edu/EP152>. 